\title{
METODOLOGI PROGRAM RISET IMRE LAKATOS
}

\author{
AHMAD SAKA FALWA GUNA ${ }^{1}$, FITRIA RAMADHANI ${ }^{2}$ \\ ${ }^{1}$ Universitas Islam Negeri Sunan Kalijaga Yogyakarta \\ ${ }^{2}$ Universitas Islam Negeri Raden Fatah Palembang \\ Email: 1ahmadsaka61@gmail.com \\ 2fitria.r987@hotmail.com
}

\begin{abstract}
This research was based on the limitations of the human mind itself in providing and obtaining reasonable explanations, because at that time the desire to know something was obstructed from various myths which existedin that society so that myths were embedded in human mind. The focus of this research was on the methodology of the Imre Lakatos research program. The purpose of this study was to determine the process of research program methodology from Imre Lakatos. The method used in this research was library research, where the researchers looked for and read sources that match the title to be studied, such as books, articles, writings and journals that were relevant. The results of this study in the Imre Lakatos research program methodology included: First, the core (hardcore) functions as a negative heuristic. Second, the protective-belt which consisted of auxiliary hypotheses in the initial conditions. Third, a series of theories (a series theory), theory linkages where the next theory was the result of the auxiliary clauses added from the previous theory.
\end{abstract}

\section{Keywords : Methodology, Program, Research}

Abstrak: Penelitian ini didasarkan dari keterbatasan pikiran manusia itu sendiri dalam memberikan dan memperoleh penjelasan yang secara masuk akal, disebabkan pada masa tersebut hasrat untuk mengetahui sesuatu terhambat dari berbagai mitos yang ada pada masyarakat tersebut sehingga tertanamnya mitos dalam pikirian manusia. Fokus penelitian ini pada metodologi program riset Imre Lakatos. Tujuan penelitian ini untuk mengetahui proses metodologi program riset dari Imre Lakatos. Adapun metode yang digunakan dalam penelitian ini adalahlibrary research, yang dimana peneliti akan mencari dan membaca sumber-sumber yang sesuai dengan judul yang akan diteliti seperti buku, artikel, tulisan dan jurnal yang relevan. Hasil dari penelitian ini dalam metodologi program riset Imre Lakatos diantaranya yaitu, Pertama inti pokok (hardcore) berfungsi sebagai heuristic negatif. Kedua, lingkaran pelindung (protective-belt) yang terdiri dari hipotesa-hipotesa bantu (auxiliary hypothese) dalam kondisi-kondisi awal. Ketiga, serangkaian teori (a series theory), keterkaitan teori dimana teori berikutnya merupakan akibat dari klausal bantu yang ditambah dari teori sebelumnya.

Kata Kunci : Metodologi, Program, Riset

\section{PENDAHULUAN}

Awal mulanya ilmu dari keinginan seseorang terhadap fenomena yang terjadi disekitar lingkungannya atau dirinya sendiri. Pada mulanya hasrat keingintahuan itu terhalang dari bermacam-macam mitos yang telah tersebar di kalangan masyarakat. Sehinga mitos tersebut tersimpan didalam pikiran masyarakat, dikarenakan 
keterbatasan dalam berpikir untuk mendapatkan dan menjelaskan dalam penjelasan secara masuk akal. Oleh sebab itu, maka harus meruntukan mitos yang telah berkembang di kalangan masyarakat dengan penjelasan secara ilmiah agar masyarakat merasakan kepuasaan dalam keingintahuannya.

Untuk mengetahui filsafat ilmu dalam pembahasannya tentu saja tidak terlepas dari pembahasan awal mula sejarah ilmu dan pengetahuan, baik itu secara pengertian, prosedur,proses, paradigma, kerangka dasar teori ilmu, jenis-jenisnya dan lain-lain. Sesuai yang telah kita ketahui, untuk bisa dikatakan bahwa ilmu harus melalui proses penelitian dahulu, dibuktikan dan seterusnya.

Kemudian, muncul para pemikir yang berusaha untuk merobohkan dengan menunjukkan filsafat baru. Salah satu pemikir dari mereka ialah Imre Lakatos. Dalam pemikiran Imre Lakatos ini didasari dari pemikiran Khun dan Popper dengan mengambil jalan tegah dari pemikiran tersebut. Imre Lakatos sangat ingin mengembangkan dan juga memberikan kritik terhadap kekurangan dalam pemikiran Popper sehingga mendapatkan hasil dengan memperoleh metode baru yang kemudian disebut Program Riset. Lakatos sangat tertarik dalam paradigma Kuhn dengan falsifikasi Popper untuk menengahi perubahan. Pemikiran Lakatos tersebut berdampingan dalam struktur teori.

Dapat dikatakan bahwa dalam menyampaikan pendapat itu merupakan sebuah teori yang didalamnya terkandung inti teori yang tidak bisa dibandingkan dengan yang lain. Oleh karena itu, penulis pada penelitian ini tertarik untuk membahas lebih mendalam mengenai metodologi program riset dari salah satu pemikir, yaitu Imre Lakatos. Hal ini meliputi biografinya, peran metodologi dalam pengembangan ilmu, pemikiran dari Imre Lakatos dan metodologi program riset dari Imre Lakatos itu sendiri.

\section{METODE PENELITIAN}

Metodelogi penelitian secara ilmiah ialah untuk mendapatkan atau memperoleh data yang akan digunakan dalam kepentingan penelitian. Pada penelitian ini termasuk kategori penelitian bidang library research, yang dimana peneliti akan mencari dan membaca sumber-sumber yang sesuai dengan judul yang akan diteliti seperti buku, artikel, tulisan dan jurnal yang relevan.

Metode penelitian dilakukan dengan cara mengumpulkan sumber-sumber buku, artikel, tulisan, opini dan jurnal yang akan mengungkap serta mengkaji dari 
metodologi program riset Imre Lakatos. Setelah data diteliti terkumpul, selanjutnya peneliti melakukan pemilahan antara buku, tulisan, artikel, dan jurnal yang membahas dari metodologi program riset Imre Lakatos dengan menggunakan metode deskriptif-analytic. Deskriptif ialah metode yang dipakai dalam pencarian fakta secara tepat, dan analisis itu ialah menguraikan pendapat secara cermat. Ketika data telah dianalisis, selanjutnya akan dipaparkan dengan menggunakan metode deduktif untuk jawaban dari penelitian ini (Syarnubi, 2019).

\section{HASIL DAN PEMBAHASAN}

\section{Biografi Imre Lakatos}

Lakatos bernama asli Imre Lipschitz, untuk menghindari ancaman dari NAZI, dia mengganti namanya menjadi Imre Molnár, namun setelah perang berakhir, dia tidak mengembalikan namanya, namun justru merubah menjadi Lakatos, yang mana dianggap mengambil dari nama Jendral Hungaria, Geza Lakatos. Imre Lakatos adalah salah seorang ilmuwan yang berasal dari Hungaria. Dia dilahirkan pada 9 Nopember 1922 dengan garis keturunan Yahudi.

Lakatos telah merampungkan pendidikan awalnya di tempat tinggalnya, walaupun pada masa tersebut di Hungaria terdampak masa-masa yang sulit, dimana pada masa itu terjadi caru marutnya perang dunia untuk dihadapi. Pada tahun 1944 Lakatos telah mendapat ijazah di kampus University of Debrecen pada bidang matematika, fisika, dan filsafat. Di tahun yang sama pada tahun 1944 Hitler telah menawarkan pada negara Hungaria dengan pilihan, apakah ingin berpihak kepada angkatan perang Jerman yang telah menguasai negara tersebut atau berpihak kepada Hilter. Pada tahun 1947 Lakatos ditunjuk sebagai Menteri Pendidikan dikarekan telah dipercaya, namun pada tahun 1950, ia dijebloskan ke penjara selama tiga tahun diakibatkan pemikirannya dianggap menyebabkan kekacauan politik. Setelah Imre Lakatos keluar dari penjara, Imre Lakatos mulai aktif dalam bidang akademik dengan menterjemahkan buku matematika ke dalam bahasa Hungaria (Aziz, 2006).

Terjadinya revolusi pada tahun 1956, sehingga membuat Lakatos kabur ke wilayah Wina yang akhirnya ia sampai ke London. Di sanalah Lakatos melanjutkan pendidikan dengan mendapatkan gelar doktor setelah berhasil mempertahankan desertasinya yang berjudul Proofs and Refutations: The Logic Of Matematical Discovery (yang mana karya Imre Lakatos ini membahas tentang pendekatan 
terhadap beberapa metodologi matematika sebagai logika penelitian) di Cambridge University (Riyanto, 2016).

Disertasinya yang berjudul Proofs and Refutations ditulis pada tahun 1963 menjadi empat bagian dalam British Journal for Philosophy of Science.Sebelum Imre Lakatos bergeser dalam bidang filsafat sains Imre Lakatos telah banyak menulis mengenai filsafat matematika. Dalam filsafat matematika karya-karyanya Imre Lakatos tersebut tampak sangat jelas berkontribusi, yang mana Imre Lakatos disini telah meyakinkan bahwa materi pokok matematika tidak akan pernah sama lagi dan membuat jadi lebih sederhana. Imre Lakatos telah membuat kita berpikir sehingga banyaknya para ahli matematika disini apa yang mereka lakukan. Imre Lakatos menulis suatu dialog filosofi yang dipelopori oleh Euler tentang tanda bukti yang mendasar sebagaimana muncul dalam ilmu geometri yang sangat mengagumkan dan merupakan karya seni intelektual yang baik. Karya tersebut diduga mirip percakapan dialog yang telah dibuat oleh Hume, Berkeley, ataupun Plato.

Demi meningkatkan dalam gagasannya mengenai tentang Metodology of Scientific Research Programmes, Imre Lakatos sering berdiskusi dengan Popper, Feyerabend, dan Kuhn semenjak menjadi guru di london school of economic, sehingga Imre Lakatos mengadakan suatu pertemuan untuk berdiskusi yang telah menghasilkan dalam mempersatukan pemikiran dari Kuhn dan Popper pada tahun 1965. Selanjutnya Imre Lakatos telah menerbitkan sebuah karya yang berjudul: Criticism and the methodology of scientific programmes, sebagai evaluasi atas prinsip falsifikasi dan upaya perbaikan atas kelemahan dan kekurangannya pada tahun 1968. Pada tanggal 2 Pebruari 1974, Lakatos meninggal dunia. Dia wafat ketika berada di London. Pada akhirnya tidak sempat untuk menyelesaikan tulisannya yang memiliki judul: The Changing Logic of Scientific Discovery, sebagai pembaharuan dari karya Popper yang berjudul: The Logic of Scientific Discovery(Muslih, 2004).

\section{Peran Metodologi dalam Pengembangan IImu}

Dalam pembahasan ini metodologi dikaitkan dengan filsafat. Untuk menghasilkan pengetahuan secara valid maka dilakukan pengujian terhadap sebuah metode dan itu merupakan fungsi dari filsafat. Sedangkan untuk menentukan sebuah prosedur yang akan dipergunakan dalam pengujian atau penciptaan preposisi untuk mendapatkan pengetahuan secara valid itu disebut metodologi. Menurut Tejoyuwono mengenai mantra metodologi penelitian yaitu sesuatu ilmu yang membahas 
mengenai kerangka kerja yang akan melakukan sebuah penelitian secara bersistem. Dalam beragumen filosofi yang didasari oleh pengetahuan didapat dari filsafat ini disebut sebagai prosedur dijustifikasi, sedangkan dalam pengetahuan berfilsafat itu bisa dihasilkan melalui epistimologi dan juga ontologi. Dalam epistimologi bisa diartikan bahwa suatu kriteria untuk memperoleh pengetahuan sesungguhnya secara riel disesuaikan dengan konsep. Epistimologi ini juga bisa mengatasi sebuah rintangan yang tidak berefektif, yang akan mengganggu dalam memproduksi pengetahuan dan ini dilakukan dengan menggunakan sistem kejelian dalam beroperasi aktivitas scientific. Ontologi adalah ilmu intisari sesuatu hal yang merupakan sub sistem keberadaannya ialah apa yang ada. Maka untuk menjawab pertanyaan "apa" tersebut, maka apa yang telah diturunkan dari oleh ontologi untuk Metodologi berhubungan dengan hakikat "ada" yang akan menjadi objek investigasi, sehingga anggapan epistimologi dan ontologi merupakan sebuah penentu bagi metodologi (Abdullah, 2011).

\section{Pendekatan Ontologi}

Pendekatan ontologi ini bisa diartikan sebagai pendekatan metafisis yang mana membahas tentang objek ilmu dan hubungan subjek dengan subjek. Objek ilmu tersebut yang terdiri dari objek material (subject matter) dan objek formal (focus of interest). Untuk objek secara material tersebut, bisa dibedakan menjadi dua hal diantaranya objek kongkret dan objek abstrak. Dikarenakan ada perbedaan diantara objek tersebut, maka lahirnya dua paham didalam metafisik ialah paham secara realisme dan paham secara idealisme. Paham realisme ini merupakan hakekat yang yang telah ada yaitu materi atau benda dikarenakan telah menitik beratkan pada sebuah kenyataan didalam ojektivitas. Kenyataannya kongkret itu bisa diketahui melalui indera manusia. Sebaliknya, paham idealisme ini bersifat rohani atau kejiwaan, oleh karena itu, kegiatan dalam berpikir, nalar dan intuisi ini bersifat abstrak disebut persepsi mental. Landasan metafisik ilmu ini terletak pada objek, apakah objek itu bersifat konkret atau bersifat abstrak. Dalam menentukan sebuah metode apa yang akan digunakan untuk memahami sesuatu maka objek ilmu sangat berpengaruh pada subjek (Abdullah, 2011).

Implisit Imre Lakatos memastikan bahwa setiap teori yang akan dilahirkan masih dalam kondisi yang "belum mapan", walaupun diantara mereka ada yang lebih baik dari pada yang lain. Imre Lakatos mentegaskan para peneliti yang sering terjebak pada "justifikasi" ini terdapat pada wilayah "protective-belt" dimana ini 
disebut teori-teori relativisme. Bagaimanapun juga, ilmu tidak akan berkembang jika dari justifikasi, dikarenakan para ilmuan hanya berfokus pada fakta yang sama ataupun sealur. Imre Lakatos mengedepankan metode heuristic ini yang sangat menarik, dikarenakan padasatu sisi Lakatos mengamankan sebuah teori besar yang telah mapan dan disisi lain Lakatos mendorong semua para ilmuwan untuk bisa menemukan sebuah teori pendamping yang memiliki basis eksperimental yang dapat meyakinkan. Dengan adanya heuristik itu berarti Imre Lakatos berada di belakang pendapat falsifikasi Popper, akan tetapi pemikiran Imre Lakatos tersebut melebihi apa yang telah dirumuskan oleh Popper. Imre Lakatos menyebutkan bahwa mereka termasuk dalam kelompok revolusioner, tetapi pendapat Popper tersebut masih perlunya disempurnakan (Aziz, 2006).

Dari konsep kerjanya Imre Lakatos, jelas bahwasannya posisi di hadapan Popper ialah menindaklanjutinya. Falsifikasi Imre Lakatos kritik, kemudian Imre Lakatos mengembangkan menjadi falsifikasi secara sofistikit. Inilah yang memiliki kekuatan dalam pemikiran sehingga ini disebut sebagai bentuk metatheory. Tulisan Imre Lakatos membahas tentang kritikan untuk kaum falsifikasionis yang telah menyatakan berhasil memecahkan persoalan induksi ini merupakan karya Imre Lakatos yaitu "Popper on Demarcation and Induction". Dalam keberhasialan Imre Lakatos dalam merumuskan cara kerja program riset ini telah membuat Imre Lakatos menduduki kembali falsifikasi dengan cara yang lebih canggih.

Kebayakan orang lebih menekuni kajian dalam filsafat, namun disini Imre Lakatos memprihatinkan mengenai akademik dalam menyangkut nilai-nilai intelektual. Imre Lakatos secara eksplisit mengatakan bahwa permasalahan dalam sentral filsafat ilmu tersebut ialah permasalahan dalam menetapkan syarat-syarat secara universal yang memerlukan teori agar bisa dinilai secara ilmiah. Imre Lakatos menyatakan bahwa permasalahan yang berkaitan erat dengan permasalahan tentang "rasionalitas ilmu" dan dalam pemecahan masalah tersebut itu harus bisa membimbing kita dalam menentukan apakah penerimaan suatu teori tersebut bisa diterima secara ilmiah-rasional atau tidak. Dalam pendapat Imre Lakatos tersebut, jika posisi relativis dianggap tidak ada standar yang lebih tinggi dari pada standar yang berada di masyarakat, maka tidak akan memberikan kesempatan kita untuk mengkritik standar tersebut. Jika kita membaca pendapat tersebut, maka sangat jelas sekali bahwa posisi Imre Lakatos ini sangat penting dikarekan telah 
memberikan peran nyata dalam pengembangan metodologi keilmuan sebagai seorang rasionalis(Aziz, 2006).

Kelemahan dari Imre Lakatos tampak sangat jelas dalam membela disiplin yang ia tekuni dan terkesan kurang menghargai disiplin yang lain. Sehingga Imre Lakatos berpendapat bahwa, tanpa memberikan argumen, maka ilmu yang telah dijelaskan dengan contoh fisika yaitu superior berada di atas dalam bentuk-bentuk pengetahuan yang tidak mengikuti ciri-ciri dari metodologisnya. Hal ini menunjukkan kelemahan dari metodologi. Sehingga Imre Lakatos mengemukakan bahwa metodologi sebagai suatu respons terhadap permasalahan dalam perbedaan rasionalitas dari irrasionalitas, dan juga terhadap penerangan masalah relevansi secara sosial-politik yang vital. Hal tersebut membuat sebagian besar Grunfeld memberikan kritik yang senada dengan metodologinya Imre Lakatos meskipun secara rasional, akan tetapi tidak secara konsisten,sehingga jika tanpa adanya konsisten maka ilmu tersebut akan berhenti sebagaimana suatu objek kajian yang secara rasional. Jawaban ini berdasarkan pada asumsiakan tetapi tanpa memberikan argumentasi(Aziz, 2006).

Secara garis besar penulis berpendapat bahwa, kelemahan yang terlihat jelas dari program riset Imre Lakatos tersebut ialah tidak adanya struktur operasional yang jelas untuk menghadapi teori-teori kecil yang saling bertarung atau disebut "protectivebelt". Bahwasannya suatu ilmu tersebut tidak akan lahir jika tanpa adanya konteks historis dan juga konteks sosio yang melatar belakanginya, maka ilmu tersebut tidak akan netral secara ontologis.

\section{Pengertian Epistemologi dan Pemikiran Epistemologi Filosuf Barat Mazhab Postivisme}

\section{a. Pengertian Epistemologi}

Epistemologi merupakan salah satu kajian filsafat yang berkaitan dengan pengetahuan. Sederhananya, epistemologi itu teori pengetahuan (Mautner, 2000). Epistemologi yang dilihat dari segi bahasa Yunani yaitu, episteme, yaitu pengetahuan dan logos, yang berarti ilmu. Dapat disimpulakan bahwa ilmu yang membahas tentang pengetahuan disebut epistemologi. Penekanan dari epistemologi tersebut ialah pengetahuan manusia sebagai makhluk yang berakal dan beradab. Secara rasional kajian epistemologi membahas dan menelurusi wilayah pengetahuan. Pembahasan ini dimaksudkan untuk mengetahui bagaimana suatu pengetahuan itu diperoleh dan juga untuk membedah batas-batas pengetahuan. Sedangkan upaya yang mencari akar permasalahan mengenai ide dan juga gagasan 
yang berhubungan dengannya, seperti memori, persepsi, indera, bukti-bukti, kepercayaan dan kepastian ini disebut proses dalam penelusuran pengetahuan.

\section{b. Pemikiran Epistemologi Filosuf Barat Mazhab Postivisme}

Mazhab ini telah lahir pada tahun 1924 dari komunitas pendiri Moritz Schlick. Dari mazhab tersebut lahirnya pandangan baru yang disebut neopositivisme atau positivisme logis. Kemudian pada abad 20 Masehi, para sarjana yang terdiri dari sarjana ilmu dan ilmu alam di Wina Austria, telah membuat komunitas yang bernama Vienna Circle (lingkaran Wina), dikarenakan mengalami kemajuan yang pesat dan mencapai kematangannya pada dominasi epistemologi positivistik. Mereka membuat batasan pada yang bermakna (meaningful) dan tidak bermakna (meaningless) untuk diverifikasi. Lalu, para sarjana Wina mengajukan dua pertanyaan yaitu How do you know?, dimaksudkan dengan "how do you verify?" dan what doyou mean? Memberikan pendapat atau analisis secara logis dari perkataan anda!" Dengan adanya dua pertanyaan tersebut, menyebabkan mereka semua menolak yang berkaitan dengan metafisika atau ungkapan teologi, seperti adanya Tuhan, penciptaan, jiwa, dan lain-lain dikarenakan dianggap tidak bermakna. Disebabkan masalah-masalah yang ada di filsafat tidak didasari dalam penggunaan bahasa yang bermakna dan dianggap semu, melainkan pada bahasa emosi dan perasaan (emotional use of language).Jadi, filsafat memiliki satu tugas, yaitu memeriksa susunan bahasa ilmiah secara logis, baik itu penyelidikan ilmu alam, ataupun matematika dan bidang logika. Epistemologi disini dipandang sebagai logika ilmu (the logic of science) (Veerhak, 1991).

Karl Raimund Popper lahir di Wina pada tahun 1902. la sangat menentang keras gagasan dari para sarjana Wina. Disini, Popper hanya menentang pada pembedaan ungkapan yang bermakna (meaningful) dan yang tidak bermakna (meaningless) berdasarkan dari kriteria yang tidak dibenarkan secara empiris. Pembedaan tersebut diganti dengan kata ungakap ilmiah dan tidak ilmiah yang diganti oleh Popper. Pokok pembedaannya terletak pada ada dan tidak adanya dasar empiris. Didalam kriteria ilmiah dan tidak ilmiah ialah falsifibilitas. Suatu ungkapan dinyatakan ilmiah jika diklasifikasikan secara empiris. Dengan pernyataan tersebut, metafisis memang tidak ilmiah, melainkan ia bermakna. Jadi, ungkapan yang secara tidak ilmiah, bisa bermakna (meaningful). Sejarah membuktikan bahwa spekulasi metafisis telah menjadi sumber ilmu empiris(Naraniecki, 2010). 
Setelah kehadiran Popper, munculnya Thomas Kuhn yang menulis tentang The Structure ofScientific Revolutions pada tahun 1962 yang membuat epistemologi mengalami perkembangan secara baru. Kuhn mengatakan, agar filsafat ilmu bisa mendekati kenyataan ilmu dan aktivitas ilmiah yang sesungguhnya maka sebaiknya harus berguru kepada sejarah ilmu baru. Konsep sentral Kuhn ini yaitu paradigma.

Menurut Kuhn fungsi paradigma akan membimbing kegiatan ilmiah dalam masa ilmu normal, ilmu yang telah matang dikuasai oleh paradigma tunggal. Paradigma tersebut akan memeriksa dan mempertanyakan seorang ilmuan jika di dalam penelitiannya terdapat gejala yang tidak bisa dijelaskan secara teori. Hal tersebut membuat ilmuan bisa mengembangkan paradigma tandingan agar dapat membimbing dan memecahkan sebuah masalah dalam penelitian selanjutnya. Menurut Kuhn untuk mengaplikasikan bahwa ilmu tersebut tidak berkembang harus secara revolusioner bukan secara kumulatif dan evolusioner. Dengan begitu, ilmu pengetahuan tidak terlepas dari faktor ruang dan waktu. Inilah yang dilakukan oleh Kuhn untuk menyerang terhadap pendirian positivistik-rasionalistik.

Pendapat dari Kuhn ini menyebabkan adanya perubahan dalam paradigma dengan gagasan revolusi ilmu pengetahuan namun masih bisa dikritik oleh Imre Lakatos. Dalam upaya bahan evaluasi dan memberikan kritik untuk kekurangan yang telah ditinggalkan oleh Kuhn, lalu Lakatos menawarkan sebuah "metodologi program riset ilmiah". Tawaran Imre Lakatos tersebut merupakan hasil dari mempersatukan pemikiran Popper dan Kuhn pada tahun 1965 dan munculnya "Metodologi Program Riset". Kemudian, Imre Lakatos memberikan bimbingan bagi riset masa depan dengan cara yang positif dan dengan cara yang negatif disebut sebagai struktur metodologis. Dalam program riset tersebut terdapat aturan-aturan metodologis, yaitu kerangka kerja konseptual sebagai konsekuensi dari bahasa yang disebut dengan "heuristik".

Heuristik merupakan suatu kewajiban dalam melakukan percobaan dan penemuan baru melalui logika secara induktif agar bisa menghindarkan kesalahan dalam memecahkan sebuah masalah. Menurut Imre Lakatos, ada tiga elemen yang berkaitan dengan program riset, yaitu : Pertama, inti pokok (hard-core). Kedua, lingkaran pelindung (protective belt) yang terdiri dari hipotesa-hipotesa bantu (auxiliary hypothese). Ketiga, serangkaian teori (a seriestheory). Elemen pertama ini merupakan inti pokok yang dilindungi dari ancaman falsifikasi dan asumsi dasar ini merupakan ciri program riset ilmiah. Elemen kedua ini merupakan lingkaran 
pelindung yang disebut "heuristik positif" berfungsi sebagai menerangkan dan meramalkan fenomena-fenomena nyata dan juga harus bisa menahan berbagai serangan, pengujian serta memperoleh penyesuaian, bahkan perubahan dan pergantian untuk mempertahankan hard-core. Elemen ketiga yaitu keterkaitan teori dimana teori berikutnya merupakan akibat dan klausul bantu yang ditambahkan dari teori sebelumnya (Lakatos \& Musgrave, 1974).

Dengan demikian, bagi Imre Lakatos, yang harus dinilai yaitu rangkaian beberapa teori baik itu secara ilmiah ataupun tidak secara ilmiah dan bukan secara teori tunggal. Dalam konteks tersebut, Imre Lakatos sangat menginginkan program riset ilmiah menjadi pandangan objektif dan mendistorsi refleksi terhadap pemikiran manusia, baik yang menciptakan maupun yang memahami dan sepenuhnya Imre Lakatos mendukung objektifitas Popper.

\section{Latar Belakang Pemikiran Imre Lakatos}

Sebelum pada masa Imre Lakatos, ilmu pengetahuan ialah akumulasi dari sebuah teori yang telah berdiri sendiri. Dari pemikiran tersebut dibantah melalui gagasan dari Thomas S. Kuhn yaitu teori relativisme dan gagasan dari Imre Lakatos. Menurut Kuhn, dalam sebuah paradigma ilmu pengetahuan ialah serangkaian teori yang kukuh. Paradigma tersebut merupakan sebuah masalah yang dapat diberikan asumsi agar bisa memberikan solusi. Dengan demikian, paradigma menjadi sumber utama bagi setiap melakukan penelitian secara normal (Sofyan, 2010).Sedangkan menurut Imre Lakatos, dalam sebuah program riset bahwa ilmu pengetahuan merupakan serangkaian teori yang kukuh.

Ada sedikit perbedaan antara Imre Lakatos dan Kuhn. Perbedaanya dalam perkembangan ilmu pengetahuan Kuhn sangat memberikan dukungan dalam terjadinya revolusi, sedangkan menurut Imre Lakatos dalam perkembangan ilmu pengetahuan ia tidak ingin terjadinya revolusi. Dikarenakan menurut Imre Lakatos, bahwa perkembangan ilmu pengetahuan tersebut dapat terjadi secara kontinu. Yang harus dinilai secara ilmiah atau tidak ilmiah yaitu serangkaian dari teori-teori tersebut bukan dari teori tunggal. Rangkaian teori tersebut, agar menjadi program riset (Research Programme) maka harus disatukan teori-teori tersebut dengan satu sama lain yang akan dihubungkan pada kontinuitas. Dalam sejarah ilmu kontinuitas memainkan peranan yang sangatlah penting. Oleh karena itu, masalah pokok yang berhubungan dengan logika penemuan tersebut harus melalui kerangka metodologi program riset(Veerhak\& Imam, 1989). 
Keberbedaan Imre Lakatos bukan berarti ia tidak mau mengapresiasi sama sekali terhadap pemikiran Popper dan Kuhn. Menurut dari pemikiran Popper, metode falsifikasi dapat dijelaskan secara sederhana, misal melalui observasi terhadap angsa-angsa putih, berapapun jumlahnya, seseorang tidak dapat menyimpulkan semua angsa tersebut berwarna putih, akan tetapi cukup satu kali saja untuk melakukan observasi pada seekor angsa hitam agar bisa menyangkal pendapat tersebut. Bukan berarti suatu hukum ilmiah dapat dibenarkan melainkan harus dapat dibuktikan. Jadi, dengan melakukan pembuktian tersebut hukum ilmiah bisa berlaku(Zubaedi, 2007).

Apa yang telah dijelaskan diatas bahwa Imre Lakatos berada di jalan tengah dari gagasan Khun dan Popper. Dengan begitu, Imre Lakatos ingin melakukan pengembangan dan memberikan kritik atas kekurangan dari gagasan Popper tersebut sehingga menghasilkan sebuah metode baru yang disebut Program Riset (Riyanto, 2011).

Berdasarkan dari beberapa argumen, maka tidak heran apabila para ilmuwan berpikir bahwa Imre Lakatos berupaya dalam memperbaiki teori-teori pemikiran dari Popper dengan mengambil hasil pemikiran Kuhn justru hal tersebut membuat Imre Lakatos dijuluki sebagai Popperian. Bahkan ada yang berpendapat bahwa hasil dari Imre Lakatos merupakan suatu pengembangan pemikiran dari Kuhn yang mengenai paradigma dan perluasan dari teori tersebut merupakan dari falsifikasi Popper. Dalam hal ini pengembangan dari pemikiran Kuhn ialah Imre Lakatos sangat memperhitungkan dan menekankan sejarah pentingnya penyusunan dalam beberapa penelitian pada masalah dan waktu yang sama. Sedangkan upaya dalam perluasan upaya yang dilakukan oleh Imre Lakatos terhadap gagasan falsifikasi Popper tampak ia menyatakan bahwa tugas utama tersebut harus menjadi program, bukan dijadikan teori sendiri-sendiri, yang terdiri dari teori-teori berganda meliputi inti (core) yang tersusun dari pendapat atau prinsip dasar, dan ikat pinggang (belt) yang terdiri dari pendapat atau prinsip jadian atau hipotesis pembantu.

\section{Metodologi Program Riset Imre Lakatos}

Metodologi program riset ini ialah sebuah hasil dari pemikiran Imre Lakatos yang ingin mempersatukan ide dari pemikiran Popper dan juga Kuhn. Dalam bentuk struktur metodologis ini metodologi program riset menawarkan sebuah jalan baru untuk para peneliti ingin mengembangkan riset di masa depan. Hal ini dilakukan 
untuk kemajuan ilmu pengetahuan dan memperbaikinya sekaligus untuk menjawab tantangan dari falsifikasionisme Popperian (Muslih, 2004).

Metodologi program riset ini didalamnya terdapat aturan mengenai tentang metodologis yang biasa disebut dengan Heuristik. Menurut The Oxford Dictionary of Philosophy Oxford Paperback Reference, Heuristik adalah sebuah proses untuk memecahkan sebuah masalah dimana tidak terdapat algoritma di dalamnya sebagaimana dengan trial and error, sehingga bisa diartikan bahwa heuristik ialah suatu aturan atau metode pendekatan untuk pemecahan masalah (Blackburn, 1996).

Kata Yunani eurike merupakan asal-usul kata heuristic dalam bahasa Inggris yang melewati dinamika trial and error ini merupakan ilmu pengetahuan yang muncul sebagai sebuah penemuan (discovery). Pertama-tama dalam IImu pengetahuan ini bukanlah untuk membuktikan masalah yang benar atau yang salah, akan tetapi insight yang ingin ditemukan sebagai pemecahan masalah (Poespowardojo, 2015). Heuristik, dalam metodologi program riset ini yang telah dikembangkan oleh Lakatos, merupakan hal yang penting dalam mengarahkan suatu jalan untuk melaksanakan riset yang ingin dilaksanakan. Standar tersebut yang dianggap sebagai ilmiah bukanlah teori tunggal yang berdiri sendiri melainkan rangkaian teori. Rangkaian teori tersebut dihubungkan dengan suatu kontinuitas bahwa teori-teori tersebut merupakan suatu program riset. Kontinuitas tersebut telah memainkan peranan yang sangat penting dalam sejarah ilmu. Untuk dapat bisa menerawang sejak awal maka kontinuitas ini telah dikembangkan dari suatu program riset (Worral \& Currie, 1989).

Menurut Imre Lakatos bahwasannya, ilmu pengetahuan tersebut bukanlah mengenai hal yang benar (verifikasi) dan juga bukanlah hal yang salah (falsifikasi), serta ilmu pengetahuan bukanlah hal sekedar trial and error, yang hanya mengumpulkan dugaan kemudian melakukan penolakan. Namun disini ilmu pengetahuan merupakan sebuah wawasan yang lebih mendalam untuk memecahkan sebuah masalah. Bahwasannya menurut pendapat dari Imre Lakatos ilmu pengetahuan tersebut merupakan sebuah program riset yang telah dibuat dan bersifat baik (progresif) (Poespowardojo, 2015).

Lakatos membandingkan teori flasifikasi dan perubahan paradigma dan menemukan kelemahan apabila keduanya dipakai sendiri-sendiri dalam upaya menyimpulkan pengetahuan yang benar. Dengan kata lain, flasifikasi dan perubahan paradigma masing-masing tidak cukup untuk menjelaskan kebenaran ilmiah, kecuali keduanya diintegrasikan dalam sebuah program riset yang telah progresif. Disini 
para falsifikasi mengajak semua para ilmuwan untuk mengembangkan sebuah teori baru (hipotesa baru) agar meninggalkan sebuah teori yang tidak bisa lagi difalsifikasikan. Perubahan dari paradigma tersebut menjelaskan bahwasannya ilmu pengetahuan terdiri dari periode-periode ilmu pengetahuan normal, yang akan bertemu dengan anomali-anomali sehingga terjadinya perubahan (Poespowardojo, 2015).

Dari apa yang telah dibandikan diatas, maka Imre Lakatos menyimpulkan sebuah metodologi untuk mengimbangkan kedua pendapat tersebut dengan metodologi program riset. Dimana metodologi program riset tersebut terdapat tiga pokok diantaranya sebagai berikut:

\section{Hard core (inti pokok)}

Hard core atau kerangka kerja terdiri dari hipotesis teoritis yang sangat umum untuk membentuk dasar dari teori ilmiah. Hard core ini memiliki hipotesis dasar yang membentuk inti pusat dari teori ilmiah dan mengembangkan atau meninggalkan teori tersebut. Kerangka ini di mana perkembangan dan perubahan dari Program riset dilaksanakan menjadi tak terbantahkan oleh keputusan metodologis pendukungnya. Dengan membentuk inti utama untuk sebuah teori. Lakatos sedang mencoba untuk menentukan kontinuitas dalam ilmu menggunakan proposisi umum. Hard core sebagai hipotesis teoritis adalah dasar dan pondasi program riset (Alihosseini \& Keshavarz, 2016). Hard core dalam Bahasa lain adalah hipotesis dasar yang tidak bisa dimodifikasi atau tidak dapat ditolak yang menjadi ciri khas dari program riset ilmiah tersebut (Worral \& Currie, 1989). "Inti pokok" tersebut telah dilindungi dari sebuah ancaman falsifikasi. Hard core disini disebut sebagai heuristik negatif, dikarenakan yang menjadi dasar di atas elemen yang lain yang disebut "inti pokok"(Muslih, 2004). Maksud dari inti pokok yang menjadi dasar diatas elemen yang lain itu adalah dikarenakan sebagai dasar bagi pengembangan program dan sifatnya menentukan dari suatu program riset serta menjadi hipotesis teoritis yang bersifat umum(Riyanto, 2011).

Sebuah progam riset akan dikatakan progresif apabila berkumpul tiga kondisi padanya (Zubaedi, 2007), yaitu:

a. Teori versi baru (teori inti dan teori bantu) mempertahankan teori-teori terdahulu yang tidak bisa dibuktikan kesalahannya.

b. Riset tersebut memiliki kandungan empiris dan hasil dari riset tersebut bisa dipakai untuk memprediksi fakta terbaru yang belum pernah ditemukan. 
C. Fakta yang telah diprediksi bisa memberikan dukungan kepada teori baru.

\section{Protective Belt (lingkaran pelindung)}

Dalam kondisi yang awal tersebut terdiri dari hipotesa bantu (auxiliary hypothese). Dalam mengartikulasikan suatu lingkaran pelindung, demi mempertahankan hard-core maka lingkaran pelindung tersebut harus bisa menahan berbagai serangan, pengujian yang diterima dan memperoleh penyesuaian, bahkan perubahan dari pengertian tersebut. Dalam aturan metodologis lingkaran pelindung ini disebut dengan "heuristic positif' yang terdiri dari saran maupun isyarat membahas tentang bagaimana memodifikasi dan meningkatkan lingkaran pelindung yang fleksibel serta bagaimana mengembangkan vaian-varian yang komplek, jadi maksudnya disini untuk menunjukkan bagaimana inti pokok dari program riset ini dilengkapi agar dapat bisa meramalkan dan menerangkan fenomena-fenomena yang nyata. Dengan mengalihkan sasaran falsifikasi kepada asumsi lain maka dengan demikian suatu teori dapat dilindungi dari ancaman falsifikasi (Zubaedi, 2007).

Lakatos menyatakan sendiri dalam bukunya yang berjudul The Methodology of Scientific Research Programmes, ia menyatakan yang artinya "heuristic positif terdiri dari sebagian perangkat isyarat tentang bagaimana mengembangkan dan mengubah varian-varian yang dapat dibantah dari suatu program riset. Hal ini yaitu bagaimana cara meningkatkan dan memodifikasi lingkaran pelindung yang selalu diperdebatkan oleh para pemikir". Lakatos menggambarkan bahwa heuristic positif dengan kisah awal teori gravitasi Newton seperti yang tertulis dalam bukunya 'Newton first worked out his programme for a planetary system with a fixed point-like sun and one single point-like planet. It was in this model that he derived his inverse square law for Kepler Ellipse'(Lakatos, 1978).

Berbeda dengan Popper yang menganggap hipotesis hanya bersifat ad hoc, Lakatos ingin memperlihatkan bahwa penggunaan hipotesis pendukung bukanlah hal yang tidak berguna, melainkan hal yang penting dalam sebuah program riset tanpa tarus bertanya apakah sebuah hipotesis benar atau salah (Poespowardojo, 2015). Dengan demikian ada dua hal yang telah ditolak oleh metodologi program riset Imre Lakatos, yaitu pertama hipotesa yang tidak dapat diuji secara independent disebut hipotesa ad hoc. Dan Kedua ialah metode kerja yang telah memperkosa inti pokok program, karena apabila hal ini dilakukan. Maka dinamika keilmuan akan semakin mundur kebelakang sehingga tidak terjadi perkembangan ilmu pengetahuan (Aziz, 2006). 


\section{A Series Theory (serangkaian teori)}

Serangkaian teori bisa diartikan dengan dimana teori yang sesudahnya merupakan akibat dari klausul bantu yang telah ditambahkan dari teori sebelumnya dan ini menjelaskan bahwa suatu teori tersebut saling berkaitan. Hal tersebutlah yang harus perlu dinilai sebagai ilmiah atau tidaknya ilmiah hanyalah serangkaian dari beberapa sebuah teori, bukan teori tunggal (Worral \& Currie, 1989). Dari hal tersebutlah untuk mendapatkan suatu ilmiah dari program riset ini harus berdasarkan dari dua syarat diantaranya sebagai berikut(Muslih, 2004):

a. Untuk program riset selanjutnya harus memenuhi derajat koherensi yang mengandung dalam perencanaan.

b. Mampu menghasilkan sebuah penemuan fenomena terbaru.

Diharapkan mampu menghasilkan perkembangan ilmu secara rasional dengan adanya struktur program tersebut. Dimana keberhasilan atau kegagalan dari suatu program riset dapat dilihat, jika program riset berhasil dilihat dari segi terjadinya perubahan yang kian maju (progresif). Akan tetapi jika suatu program riset yang dinyatakan gagal maka hanya bisa dilihat dari segi menghasilkan temuan yang justru merosot (degeneratif). Dengan demikian, maka akan semakin terbuka lebar untuk berdiskusi, dikritik dan dikembangkan agar "konten empirik" menjadi lebih besar, hal inilah yang membuat suatu teori menjadi lebih baik atau superior. Dikarenakan dinamika ilmu merupakan akumulasi teori yang selalu diperkaya dengan hasil empiris (Riyanto, 2016).

Jadi, pada dasarnya sejak dahulu sejarah ilmu memang telah ada dan merupakan sejarah bagi para pemikir yang saling bersaing dalam memperbanyak program riset. Oleh sebab itu, heuristic power (kekuatan pengembangan) dan continuity (keberlanjutan) sangat diperlukan dalam kegiatan mengembangkan ilmu (Losee, 2001). Imre Lakatos memberikan gagasannya bahwa dalam mempertahankan hard core merupakan misi utama dari setiap pola program riset ilmiah, hanya saja pada tatanan protective belt yang harus difalsifikasikan. Menurut dari Imre Lakatos bahwa dalam mengembangkan suatu ilmu pengetahuan itu terjadi secara kontinyu. Terlebih lagi dalam perkembangan ilmu pengetahuan Imre Lakatos menolak terjadinya revolusi. Oleh karena itu, dapat diambil kesimpulan bahwa disinilah letak perbedaan antara Popper, Kuhn dan Lakatos. 


\section{PENUTUP}

Imre Lakatos merupakan seorang ilmuwan yang lahir di Hungaria pada 9 Nopember 1922. la menyelesaikan studi pada bidang Matematika, Fisika, dan Filsafatdi University of Debrecen. Imre Lakatos menerbitkan sebuah karya yang berjudul: Criticism and the methodology of scientific programmes pada tahun 1968. Dan pada tanggal 2 Februari tahun 1974 sebelum menyelesaikan karya yang berjudul: "The Changing Logic Of Scientific Discovery". Imre Lakatos meninggal dunia di London. Dalam pemikiran Imre Lakatos terdapat banyak pemikiran dari Popper yang membahas tentang falsifikasi dan juga tentang adanya paradigma dalam ilmu pengetahuan dari pemikiran Kuhn. Sehingga Imre Lakatos menggabungkan hasil dari pemikiran kedua tokoh tersebut dan akhirnya munculnya gagasan dari Imre Lakatos yaitu metodologi program riset, bahwa ilmu pengetahuan tersebut harus dibuktikan melalui jalan program riset. Terdapat tiga elemen-elemen penting dalam metodologi program riset Imre Lakatos, yaitu: (1) Inti pokok (hardcore) berfungsi sebagai heuristic negatif. (2) Lingkaran pelindung (Protective-belt) yang terdiri dari hipotesa bantu (auxiliary hypothese) dalam kondisi awal. (3) Serangkaian teori (a series theory). Dimana teori sesudahnya merupakan akibat dari klausul bantu yang telah ditambahkan dari teori sebelumnya dan ini menjelaskan bahwa suatu teori tersebut saling berkaitan.

\section{DAFTAR RUJUKAN}

Abdullah, M. (2011). Pengembangan Teori Akuntasi Berbasis Filsafat IImu. Jurnal Akuntasi, 2(No. 2), hlm. 141.

Alihosseini, A., \& Keshavarz, H. (2016). Lakatos's Research Program and The Thought of The Islamic Republic. Journal Modern Applied Science, 10(No. 3), hlm. 58.

Aziz, A. A. (2006). Pemikiran Imre Lakatos (1922-1974) Tentang Metodologi Program Riset dan Signifikasinya dalam Kajian Keislaman. Jurnal Islamica, 1(No. 1), hlm. 43.

Blackburn, S. (1996). The Oxford Dictionary of Philosophy Oxford Paperback Reference. Oxford: Oxford University Press.

Lakatos, I. (1978). The Methodology of Scientific Research Programmes. New York: Cambridge University Press.

Lakatos, I., \& Musgrave, A. (1974). Falsification and The Methodology of Scientific Research Programmes dalam Criticism and The Growth of Knowledge. 
Cambridge: Cambridge University Press.

Losee, J. (2001). A Historical Introduction to The Philosophy of Science. New York: Oxford University Press.

Mautner, T. (2000). The Penguin Dictionary of Philosophy. London: Penguin Book Ltd.

Muslih, M. (2004). Filsafat IImu. Yogyakarta: Belukar.

Naraniecki, A. (2010). Neo-Positivist or Neo-Kantian? Karl Popper and the Vienna Circle. Journal Philosophy, 85(No. 4), hlm. 511-530.

Poespowardojo, T. M. S. (2015). Filsafat IImu Pengetahuan. Jakarta: Gramedia Pustaka Utama.

Riyanto, W. F. (2011). Filsafat IImu Topik-Topik Epistemologi. Yogyakarta: Integrasi Interkoneksi Press.

Riyanto, W. F. (2016). Filsafat IImu Topik-Topik Epistimologi. Yogyakarta: Integrasi Interkoneksi Press.

Sofyan, A. (2010). Kapita Selekta Filsafat. Bandung: Pustaka Setia.

Syarnubi. (2019). Guru yang Bermoral dalam Konteks Sosial, Budaya, Ekonomi, Hukum dan Agama (Kajian Terhadap UU No. 14 Tahun 2005 Tentang Guru dan Dosen). Jurnal PAI Raden Fatah, Vol. 1(1), hlm. 22.

Veerhak, C. (1991). Filsafat IImu Pengetahuan, Telaah Atas Cara Kerja IImu. Jakarta: Gramedia Pustaka Utama.

Veerhak, C., \& Imam, R. H. (1989). Filsafat IImu Pengetahuan. Jakarta: Gramedia Pustaka Utama.

Worral, J., \& Currie, G. (1989). Falsification and The Methodology of Scientific Research Programmes dalam The Methodology of Scientific Research Programmes. New York: Cambridge University Press.

Zubaedi. (2007). Filsafat Barat: Dari Logika Baru Rene Descartes Hingga Revolusi Sains. Yogyakarta: Ar-Ruzz Media. 